\title{
The effect of heat on SARS-CoV-2 viability and RNA integrity as determined by plaque
} assay, virus culture and real-time RT-PCR

\section{Jane Burton*, Hannah Love, Kevin Richards, Christopher Burton, Sian Summers, James Pitman, Linda Easterbrook, Katherine Davies, Peter Spencer, Marian Killip, Patricia Cane, Christine Bruce, Allen D G Roberts.}

High Containment Microbiology, Public Health England, Porton Down, Salisbury SP4 0JG.

Corresponding Author: jane.burton@phe.gov.uk

\begin{abstract}
The effect of heat on SARS-CoV-2/England/2/2020 viability was assessed by plaque assay and virus culture. Heating to $56^{\circ} \mathrm{C}$ and $60^{\circ} \mathrm{C}$ for 15,30 and 60 minutes led to a reduction in titre of between 2.1 and $4.9 \log _{10} \mathrm{pfu} / \mathrm{ml}$ but complete inactivation was not observed. At $80^{\circ} \mathrm{C}$ plaques were observed after 15 and 30 minutes of heating, however after 60 minutes viable virus was only detected following virus culture. Heating to $80^{\circ} \mathrm{C}$ for 90 minutes and $95^{\circ} \mathrm{C}$ for 1 and 5 minutes resulted in no viable virus being detected. At $56^{\circ} \mathrm{C}$ and $60^{\circ} \mathrm{C}$ significant variability between replicates was observed and the titre often increased with heat-treatment time. Nucleic acids were extracted and tested by RT-PCR. Sensitivity of the RT-PCR was not compromised by heating to $56^{\circ} \mathrm{C}$ and $60^{\circ} \mathrm{C}$. Heating to $80^{\circ} \mathrm{C}$ for 30 minutes or more and $95^{\circ} \mathrm{C}$ for 1 or 5 minutes however, resulted in an increase of at least three $\mathrm{Ct}$ values. This increase remained constant when different dilutions of virus underwent heat treatment. This indicates that high temperature heat inactivation of clinical samples prior to nucleic acid extraction could significantly affect the ability to detect virus in clinical samples from patients with lower viral loads by RT-PCR.
\end{abstract}

Key Words: SARS-CoV-2; heat inactivation;

\section{Introduction}

The current pandemic of SARS-CoV-2 has led to an unprecedented global expansion in laboratory testing for the viral nucleic acids and antibodies against the virus. The severity of the disease, route of transmission and the lack of prophylaxis fulfils the criteria for the virus being handled as a BSL3/ACDP 3 agent, as are the related viruses SARS-CoV and MERS-CoV (1). Propagation of SARS-CoV-2 requires the use of BSL3/ACDP3 laboratories (2). In the UK, to provide the extremely high throughput required, the processing of clinical samples for diagnostic purposes has been derogated to $\operatorname{BSL2/ACDP2}(3,4)$. To protect laboratory staff conducting SARS-CoV-2 diagnostic testing and research outside of BSL3/ACDP3, effective methods of inactivating live virus present in clinical samples and other virus-infected material are essential.

Heating at $56^{\circ} \mathrm{C}$ for 30 minutes is commonly used to inactivate complement in serum samples for serological investigations. This has been shown to have no adverse effect on IgA and IgG ELISAs (5) and is also used to inactivate live virus present in clinical samples (6). This 
temperature has been found to be effective for many but not all viruses $(7,8)$. The effectiveness of heat on the inactivation of SARS-CoV-2 can be influenced by numerous factors including the type of sample, heat source, tube type and the length of time that the samples are heated (e.g. including or excluding the time taken for the samples to reach the target temperature). A recent comparison of available literature for the effect of heat on previously described coronaviruses (9) has shown considerable variation between and within studies. Overall, it concludes that for SARS-COV and MERS-CoV, heating to $60^{\circ} \mathrm{C}$ for $30 \mathrm{~min}, 65^{\circ} \mathrm{C}$ for $15 \mathrm{~min}$ and $80^{\circ} \mathrm{C}$ for $1 \mathrm{~min}$ reduces virus infectivity by at least $4 \log _{10}$. Previous studies using SARS-CoV have demonstrated that the efficacy of heat inactivation is reduced in samples with higher protein content (e.g. Foetal Calf serum (FCS), human serum or Bovine Serum Albumen) (10-12) For successful inactivation the British Standard for virus inactivation (13) recommends a $4 \log _{10}$ or greater reduction in titre.

Complete inactivation of SARS-CoV-2 has been reported at $56^{\circ} \mathrm{C}$ after 45 minutes and $100{ }^{\circ} \mathrm{C}$ after 5 minutes (14), with an observed increase in titre between 15 and 30 minutes incubation at $56^{\circ} \mathrm{C}$. Other studies suggest that SARS-CoV- 2 can be inactivated in less than 30 minutes, 15 minutes and 3 minutes at $56^{\circ} \mathrm{C}, 65^{\circ} \mathrm{C}$ and $95^{\circ} \mathrm{C}$ respectively $(15,16)$. Again, when testing at $37^{\circ} \mathrm{C}$ and $42^{\circ} \mathrm{C}$, an increase in titre was observed between 15 and 30 minutes, and 30 and 60 minutes ref. For virus-spiked nasopharyngeal and human serum samples, greater than $5 \log _{10}$ reductions in viral titres have been reported for heat treatments of $56^{\circ} \mathrm{C}$ for 30 minutes and $60^{\circ} \mathrm{C}$ for 60 minutes. In virus culture supernatant alone, virus titre reductions greater than $6 \log _{10}$ for $95^{\circ} \mathrm{C}$ for 15 minutes have been demonstrated (17).

Most of the studies on the effect of heat on coronaviruses have used TCID 50 . This may be less sensitive than use of the plaque assay $(10,17-19)$ to determine virus titre in heat-treated compared to untreated samples. None of the studies further subjected the samples to virus culture and RT-PCR to determine the presence of viable virus below the limit of detection of the $\mathrm{TCID}_{50}$ assay.

The aim of this study was to determine the effect of heat on the viability of SARS-CoV-2 in tissue culture medium using plaque assay to determine the titre followed by more sensitive detection of live virus by culture followed by RT-PCR. In addition, the effect of virus heat treatment on RTPCR sensitivity was evaluated.

\section{Materials and Methods}

\subsection{Virus}

The virus stock used was a P3 working bank grown from SARS-CoV-2 Strain England 2, a clinical isolate taken during acute illness, propagated in Vero E6 cells. The stock was prepared by infecting 95\% confluent Vero $\mathrm{E} 6$ cells with virus to an $\mathrm{MOI}$ of 0.005 . Virus was harvested after 6 days. The titre was determined to be $7.0 \times 10^{5} \mathrm{pfu} / \mathrm{ml}$ by plaque assay as described below.

\subsection{Heat inactivation.}

\subsubsection{Test samples}


bioRxiv preprint doi: https://doi org/10.1101/2020.11.02.365015; this version posted November 2, 2020. The copyright holder for this preprint (which was not certified by peer review) is the author/funder, who has granted bioRxiv a license to display the preprint in perpetuity. It is made available under aCC-BY-ND 4.0 International license.

For each heat treatment $3 \times 1 \mathrm{ml}$ volumes of virus in tissue culture medium (MEM $+4 \% \mathrm{FCS}$ ) were tested. Heat treatments of $56^{\circ} \mathrm{C}, 60^{\circ} \mathrm{C}$ and $80^{\circ} \mathrm{C}$ for 15,30 and $60 \mathrm{~min}, 80^{\circ} \mathrm{C}$ for $90 \mathrm{~min}$ and $95^{\circ} \mathrm{C}$ for 1 and 5 min were tested.

\subsubsection{Heat treatment}

Heating was carried out in an unlidded mini dry hot block. The temperature of the different wells in the block was validated before use using a Digitron thermal probe (2024T) inserted in a non-skirted Sarstedt tube (A2034) containing $1 \mathrm{ml}$ of water. Heating was achieved by placing 1 $\mathrm{ml}$ volumes of virus in the hot block at the same time as an identical tube containing $1 \mathrm{ml}$ of water and the thermal probe. The incubation time was started when the liquid in the control tube reached the required temperature (this usually took approximately 10 minutes). At the end of the incubation time tubes were placed on ice before the plaque assay was carried out. Untreated tubes were left on ice whilst the heating step was carried out.

\subsection{Plaque assay}

24 well flat-bottomed cell culture plates (Thermo Scientific) were seeded with $3.0 \times 10^{5} / \mathrm{ml}$ Vero E6 cells in $0.5 \mathrm{ml}$ volumes of $2 \times$ MEM medium containing Glutamax ( $2 \times$ MEM Gibco ) + $10 \%$ FCS (Sigma, ) $+1 \times$ (final concentration) NEAA (Gibco, ) $+1 \times$ antibiotic-antimycotic (Gibco) and incubated overnight at $37^{\circ} \mathrm{C}+5 \% \mathrm{CO}_{2}$. Before use the cells were checked for confluency. Each virus sample was tested in triplicate. Triplicate 10 -fold dilutions up to $10^{-6}$ of each sample were made in a microtitre plate (Costar). The medium was removed from the 24 well plate and $100 \mu$ of each dilution was added to the appropriate well. Plates were incubated at room temperature with occasional rocking for 1 hour, then $0.5 \mathrm{ml}$ overlay (final concentration of $1.5 \%$ CMC (Sigma), $1 \times$ MEM, 4\% FCS and $1 \times$ Anti-anti) added to each well. Plates were incubated for 72 hours at $37^{\circ} \mathrm{C}$.

Plates were fixed for 1 hour with 4\% formaldehyde in PBS then washed three times with water and allowed to dry. Plates were stained with $250 \mu$ of $1 \%$ Crystal Violet (Sigma) for 10 - 15 minutes, washed twice with water, dried and the number of plaques counted and recorded.

\subsection{Virus detection by serial passage}

$500 \mu \mathrm{l}$ of each heat-treated or untreated virus sample was added to a $12.5 \mathrm{~cm}^{2}$ flask of $80 \%$ confluent Vero E6 cells, allowed to adsorb for 60 minutes at room temperature then $2.5 \mathrm{ml}$ of $\mathrm{MEM}+4 \% \mathrm{FCS}$ was added. Two negative control flasks to which $500 \mu \mathrm{lMEM}+4 \% \mathrm{FCS}$ was added in place of virus, were set up in parallel. At the beginning and end of each passage, $140 \mu \mathrm{l}$ samples of culture supernatant were added to AVL ( $560 \mu$ l; QIAamp viral RNA mini kit (Qiagen) in duplicate. After 10 minutes, $560 \mu \mathrm{l}$ of $100 \%$ ethanol was added. Nucleic acids were extracted according to the manufacturer's instructions and eluted in $60 \mu \mathrm{l}$ AVE buffer. RT-PCR analysis was conducted as described in Section 2.6. After one week cells were observed for signs of cytopathic effect (cpe) by viewing under a low magnification microscope. Samples for which no cpe was observed were passaged using the above method up to 3 times to allow amplification of any low volumes of virus present in the sample. After the first passage a single positive (control) and negative flask were passaged on. 


\subsection{RNA integrity following heat treatment}

SARS-CoV-2 virus was diluted to give $1 \mathrm{ml}$ volumes of $7.0 \times 10^{4}, 7.0 \times 10^{2}$ and $7.0 \mathrm{pfu} / \mathrm{ml}$. One sample from each dilution was subjected to heat treatment as described in Section 2.2. Duplicate $140 \mu \mathrm{l}$ samples were taken from each tube into AVL and RNA extracted as described above.

\section{$2.6 \quad R T-P C R$}

Nucleic acids were stored frozen at $-80^{\circ} \mathrm{C}$ until they were subjected to RT-PCR in suitable batches with initial (day 0) and final (day 7) samples from each passage in the same run. RT-PCR was carried out on an Applied Biosystems Fast 7500 PCR machine in standard run mode using the SARS-CoV E Sarbeco assay $(20,21)$ using MS2 as an internal extraction control $(22)$. The master mix comprised Egene $F$ and $R$ primers and TM-P ( $400 \mathrm{nM}, 400 \mathrm{nM}$ and $200 \mathrm{nM}$ final concentration respectively), MS2 primers and TM probe ( $20 \mathrm{nM}, 20 \mathrm{nM}$ and $40 \mathrm{nM}$ final concentration respectively), $4 \times$ TaqMan $^{\circledR}$ Fast Virus 1-Step Master Mix made up with molecular-grade nuclease free water (Ambion) to a final volume of $15 \mu$ l. The amount of template material added was $5 \mu$ l. Cycling conditions were $55^{\circ} \mathrm{C}$ for $10 \mathrm{~min}$, followed by $94^{\circ} \mathrm{C}$ for $3 \mathrm{~min}$ then $45 \mathrm{cycles}$ of $95^{\circ} \mathrm{C}$ for $15 \mathrm{~s}$ and $58^{\circ} \mathrm{C}$ for $30 \mathrm{~s}$.

\section{Results}

\subsection{Effect of heat on the viability of SARS-CoV-2}

The effect of heat on SARS-CoV-2 virus viability as determined by plaque assay is shown in Figure 1 and Table 1. A $4 \log _{10}$ or greater reduction in titre was consistently observed in all replicates after $56^{\circ} \mathrm{C}$ for 30 minutes, $80^{\circ} \mathrm{C}$ for 90 minutes and $95^{\circ} \mathrm{C}$ for 1 and 5 minutes. Significant variation in heattreatment efficacy was observed between replicates. At $56^{\circ} \mathrm{C}$ and $60^{\circ} \mathrm{C}$ the plaque assay titre increased with longer periods of heat treatment (Figure 1). The sensitivity of the plaque assay was 3 $\mathrm{pfu} / \mathrm{ml}$.

In all untreated and $56^{\circ} \mathrm{C}$ heated samples, cpe was observed and growth of virus was detected by SARS-CoV specific RT-PCR (as defined by a decrease in Ct value between nucleic acid samples extracted on day 0 and day 7) for each passage (Table 1). At $60^{\circ} \mathrm{C}, 3$ of 6 replicates (from two separate experiments) showed virus growth (by cpe and RT-PCR) after 15 and 30 minutes and 5 of 6 after 60 minutes of heat-treatment. There was greater virus recovery after 60 minutes incubation at this temperature compared to shorter incubation times. At $80^{\circ} \mathrm{C}$ viable virus was recovered from 3 replicates where no plaques were observed. No virus was recovered or virus growth detected by RT-PCR from samples heated to $80^{\circ} \mathrm{C}$ for 90 minutes or $95^{\circ} \mathrm{C}$ for 1 or 5 minutes. All replicates showed $100 \%$ correlation between observation of cpe and detection of virus growth by RT-PCR.

\subsection{The effect of heat on RNA integrity and RT-PCR assay sensitivity}

Heat-treatment of virus to $56^{\circ} \mathrm{C}$ or $60^{\circ} \mathrm{C}$ had little effect on RNA integrity as measured by the sensitivity of RT-PCR (Table 1). Heating to $80^{\circ} \mathrm{C}$ for 30 minutes or more, however, resulted in an increase of at least three $\mathrm{Ct}$ values, equating to a log reduction in sensitivity of the RT-PCR. The $\mathrm{Ct}$ 
bioRxiv preprint doi: https://doi org/10.1101/2020.11.02 365015; this version posted November 2,2020 . The copyright holder for this preprint (which was not certified by peer review) is the author/funder, who has granted bioRxiv a license to display the preprint in perpetuity. It is made available under aCC-BY-ND 4.0 International license.

value further increased the longer the virus was heat-treated, with an increase of ten or more $\mathrm{Ct}$ values observed for samples held at $80^{\circ} \mathrm{C}$ for 60 or 90 minutes. Heating to $95^{\circ} \mathrm{C}$ for 1 or 5 minutes led to an increase in $\mathrm{Ct}$ of around 6 . When different virus dilutions were heat-treated and tested by RT-PCR, the increase in Ct value observed after virus had been heated remained (Table 2 ) and as expected, greater variability between $\mathrm{Ct}$ values was observed when the initial RNA concentration was lower. After 60 minutes heating at $80^{\circ} \mathrm{C}$ the $\mathrm{Ct}$ value increased (compared to control virus that had not been heat-treated) by 10 and 14 for viruses at $7.0 \times 10^{4}$ and $7.0 \times 10^{2} \mathrm{pfu} / \mathrm{ml}$ respectively, whilst the virus at $7.0 \times 10^{1} \mathrm{pfu} / \mathrm{ml}$ was rendered undetectable by RT-PCR. 


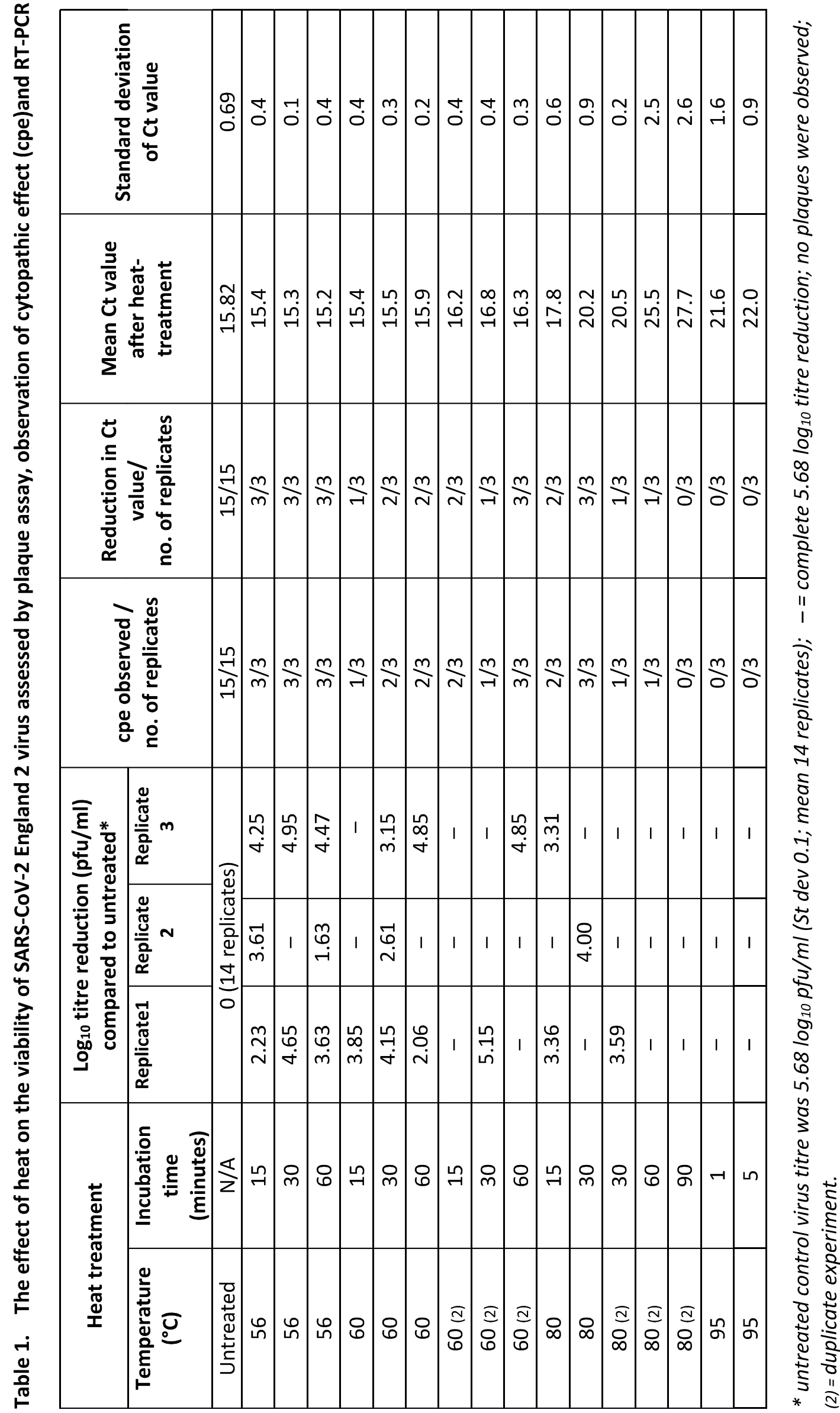


Table 2. Ct values of SARS-CoV-2 RNA extracted from heat treated virus.

\begin{tabular}{|c|c|c|c|c|}
\hline \multicolumn{2}{|c|}{ Heat treatment } & \multicolumn{3}{|c|}{ Ct Value } \\
\hline $\begin{array}{c}\text { Temperature } \\
\left({ }^{\circ} \mathrm{C}\right)\end{array}$ & $\begin{array}{c}\text { Time } \\
\text { (minutes) }\end{array}$ & $\begin{array}{l}7.0 \times 10^{4} \\
(\mathrm{pfu} / \mathrm{ml})\end{array}$ & $\begin{array}{l}7.0 \times 10^{2} \\
(\mathrm{pfu} / \mathrm{ml})\end{array}$ & $\begin{array}{l}7.0 \times 10^{1} \\
(\mathrm{pfu} / \mathrm{ml})\end{array}$ \\
\hline untreated & $\mathrm{N} / \mathrm{A}$ & 17.2 & 23.2 & 30.2 \\
\hline 56 & 60 & 18.6 & 24.3 & 30.5 \\
\hline 80 & 15 & 18.1 & 24.8 & 28.8 \\
\hline 80 & 30 & 21.0 & 29.6 & 29.6 \\
\hline 80 & 60 & 28.1 & 37.5 & $U$ \\
\hline 80 & 90 & 25.8 & 35.4 & $U$ \\
\hline 95 & 1 & 18.8 & 26.6 & 32.5 \\
\hline 95 & 5 & 21.7 & 29.4 & 36.2 \\
\hline
\end{tabular}

Each Ct value is the mean from duplicate RNA extractions; $N / A=$ Not applicable. $U=C t$ undetermined (RNA not detected)

\section{Discussion}

In this study a $4 \log _{10}$ or greater reduction in virus titre was consistently observed in all replicates after $56^{\circ} \mathrm{C}$ for 30 minutes, $80^{\circ} \mathrm{C}$ for 90 minutes and $95^{\circ} \mathrm{C}$ for 1 and 5 minutes. Complete inactivation was observed after heating to $80^{\circ} \mathrm{C}$ for 90 minutes and $95^{\circ} \mathrm{C}$ for 1 and 5 minutes. As independent confirmation of our results, heat treatment at $56^{\circ} \mathrm{C}$ was also tested in a different PHE laboratory by $\mathrm{TCID}_{50}$ using a separate virus stock (concentration $7.0 \log _{10} \mathrm{TCID} \mathrm{D}_{50} / \mathrm{ml}$ ). After 15, 30 and 60 minutes a 3.5, 5.3 and $4.3 \log _{10} \mathrm{TCID}_{50} / \mathrm{ml}$ reduction in titre was observed. Taken together with our results, this is in agreement with results described by Pastorino et al. (18). It contradicts the findings of other studies where $56^{\circ} \mathrm{C}$ for 30 (15); (16)) or 45 minutes (14) or $80^{\circ} \mathrm{C}$ for $60 \mathrm{~min}$ (23) was shown to completely inactivate the virus. This variation is potentially due to differences in the sample volumes subjected to heat treatment. In this study $1 \mathrm{ml}$ volumes were tested to allow triplicate plaque assays and virus culture to be carried out. For high-throughput processing the volume of clinical sample required can be $600 \mu \mathrm{l}$. The other studies quoted tested volumes of $500 \mu \mathrm{l}$ or less. Another source of variation is the method of virus titration. This study used plaque assays (the gold standard for quantifying replication-competent lytic virions as plaque-forming units (24)), serial passage in cell culture and RT-PCR in combination to demonstrate the presence of viable virus below the limit of detection of the plaque assay and the effect of heat treatment on RNA integrity. These methodologies in combination are more sensitive than using titration alone. Another consideration is the potential variation in temperature that can occur when using a hot block. Although the hot block in this study was carefully monitored there have been reports that the use of hot blocks can result in unequal heating, hotspots, or spikes in temperature(25).

Interestingly, in this study at both $56^{\circ} \mathrm{C}$ and $60^{\circ} \mathrm{C}$ the number of plaques observed increased with longer treatment times. This is in agreement with findings using SARS-CoV (19) and has also been reported for SARS-CoV-2 at $56^{\circ} \mathrm{C}(14)$ and at $37^{\circ} \mathrm{C}$ and $42^{\circ} \mathrm{C}$ (16). One possible explanation for this 
bioRxiv preprint doi: https://doi.org/10.1101/2020.11.02.365015; this version posted November 2, 2020. The copyright holder for this preprint (which was not certified by peer review) is the author/funder, who has granted bioRxiv a license to display the preprint in perpetuity. It is made available under aCC-BY-ND 4.0 International license.

phenomenon may be the formation and subsequent dissociation of virus aggregates in response to heat (19). Virus aggregates would produce individual plaques in cell culture identical to those observed for individual virions, resulting in an underestimate of the true number of infectious virus particles in aggregated samples. True inactivation of disaggregated virions may occur after longer incubation times or at higher temperatures.

The reduction of virus RNA integrity observed in the RT-PCR assays correlated with the increased temperature and length of heat treatment. Integrity was not significantly affected by heating to $56^{\circ} \mathrm{C}$ and $60^{\circ} \mathrm{C}$. This is in agreement with some studies $(17,26)$ but not others $(27,28)$. In this study we found that heating to $80^{\circ} \mathrm{C}$ for 30 minutes or more led to an increase in Ct value and therefore a reduction in RT-PCR sensitivity that could impact upon clinical diagnosis. The less notable increase in $\mathrm{Ct}$ value observed when virus was heated to $95^{\circ} \mathrm{C}$ in this study could be attributed to the shorter heating time. Further work needs to be done before in-depth conclusions can be drawn, however, preserving RNA integrity should be a consideration for downstream processing requiring high sensitivity such as clinical diagnostic RT-PCRs. Heat treatment at lower temperatures combined with chemical inactivation, short duration high-temperature heat treatments, or chemical inactivation alone may be more appropriate to preserve RNA integrity and optimise PCR detection of SARS-CoV-2 RNA from low titre clinical samples.

In this study the effect of heat was tested on virus-infected tissue culture supernatant. It is likely that in some cases heat treatment would be even more variable in clinical samples although this has not always been reported (29). Our results show significant variation in the effectiveness of heat treatment for inactivation of SARS-CoV-2. This emphasises the importance of local validation of inactivation methods and the need for consistency in inactivation protocols to ensure sufficient reduction in virus titre for processing of clinical samples and research material in BSL2/ACDP2 facilities.

This research did not receive any specific grant from funding agencies in the public, commercial or not-for-profit sectors.

Declarations of competing interest of authors: None.

\section{References}

1. Barkham TM. 2004. Laboratory safety aspects of SARS at Biosafety Level 2. Ann Acad Med Singapore 33:252-256.

2. WHO. 2020. World Health Organization Laboratory biosafety guidance related to the novel coronavirus (2019-nCoV).

3. PublicHealthEngland. 2020. COVID-19: guidance for sampling and for diagnostic laboratories.

4. Bain W, Lee JS, Watson AM, Stitt-Fischer MS. 2020. Practical Guidelines for Collection, Manipulation and Inactivation of SARS-CoV-2 and COVID-19 Clinical Specimens. Curr Protoc Cytom 93:e77.

5. Hu X, Zhang R, An T, Li Q, Situ B, Ou Z, Wu C, Yang B, Tian P, Hu Y, Ping B, Wang Q, Zheng L. 2020. Impact of Heat-Inactivation on the detection of SARS-CoV-2 IgM and IgG Antibody by ELISA. Clin Chim Acta doi:10.1016/j.cca.2020.06.032. 
bioRxiv preprint doi: https://doi.org/10.1101/2020.11.02.365015; this version posted November 2, 2020. The copyright holder for this preprint (which was not certified by peer review) is the author/funder, who has granted bioRxiv a license to display the preprint in perpetuity. It is made available under aCC-BY-ND 4.0 International license.

6. Huang YJ, Hsu WW, Higgs S, Vanlandingham DL. 2015. Temperature Tolerance and Inactivation of Chikungunya Virus. Vector Borne Zoonotic Dis 15:674-677.

7. Park SL, Huang YJ, Hsu WW, Hettenbach SM, Higgs S, Vanlandingham DL. 2016. Virusspecific thermostability and heat inactivation profiles of alphaviruses. J Virol Methods 234:152-155.

8. Pfaender S, Brinkmann J, Todt D, RiebesehI N, Steinmann J, Steinmann J, Pietschmann T, Steinmann E. 2015. Mechanisms of methods for hepatitis C virus inactivation. Appl Environ Microbiol 81:1616-1621.

9. Kampf G, Voss A, Scheithauer S. 2020. Inactivation of coronaviruses by heat. J Hosp Infect doi:10.1016/j.jhin.2020.03.025.

10. Rabenau HF, Cinatl J, Morgenstern B, Bauer G, Preiser W, Doerr HW. 2005. Stability and inactivation of SARS coronavirus. Med Microbiol Immunol 194:1-6.

11. Yunoki M, Urayama T, Yamamoto I, Abe S, Ikuta K. 2004. Heat sensitivity of a SARSassociated coronavirus introduced into plasma products. Vox Sanguinis 87:302-303.

12. Chang L, Yan Y, Wang L. 2020. Coronavirus Disease 2019: Coronaviruses and Blood Safety. Transfus Med Rev doi:10.1016/j.tmrv.2020.02.003.

13. 14885:2018 BE. 2018. Chemical disinfectants and antiseptics. Application of European Standards for chemical disinfectants and antiseptics.

14. Jureka AS, Silvas JA, Basler CF. 2020. Propagation, Inactivation, and Safety Testing of SARSCoV-2. Viruses 12.

15. Batéjat, G, M, I. 2020. Heat inactivation of the Severe Acute Respiratory Syndrome Coronavirus 2

16. Wang T. T CZLCZ, Liu S 1, SP. 2020. Effective Heat Inactivation of SARS-CoV-2 medRxiv preprint doi: https://doiorg/101101/2020042920085498.

17. Pastorino BT, F.; Gilles, M.; de Lamballerie, X.; Charrel, R.N. . 2020. Heat Inactivation of Different Types of SARS-CoV-2 Samples: What Protocols for Biosafety, Molecular Detection and Serological Diagnostics? Viruses 12:735.

18. Leclercq I, Batéjat C, Burguière AM, Manuguerra JC. 2014. Heat inactivation of the Middle East respiratory syndrome coronavirus. Influenza Other Respir Viruses 8:585-586.

19. Darnell ME, Subbarao K, Feinstone SM, Taylor DR. 2004. Inactivation of the coronavirus that induces severe acute respiratory syndrome, SARS-CoV. J Virol Methods 121:85-91.

20. Corman VM, Landt O, Kaiser M, Molenkamp R, Meijer A, Chu DK, Bleicker T, Brünink S, Schneider J, Schmidt ML, Mulders DG, Haagmans BL, van der Veer B, van den Brink S, Wijsman L, Goderski G, Romette JL, Ellis J, Zambon M, Peiris M, Goossens H, Reusken C, Koopmans MP, Drosten C. 2020. Detection of 2019 novel coronavirus (2019-nCoV) by realtime RT-PCR. Euro Surveill 25.

21. Pezzi L, Charrel RN, Ninove L, Nougairede A, Molle G, Coutard B, Durand G, Leparc-Goffart I, de Lamballerie X, Thirion L. 2020. Development and Evaluation of a duo SARS-CoV-2 RTqPCR Assay Combining Two Assays Approved by the World Health Organization Targeting the Envelope and the RNA-Dependant RNA Polymerase (RdRp) Coding Regions. Viruses 12.

22. Rolfe KJ, Parmar S, Mururi D, Wreghitt TG, Jalal H, Zhang H, Curran MD. 2007. An internally controlled, one-step, real-time RT-PCR assay for norovirus detection and genogrouping. J Clin Virol 39:318-321.

23. Patterson EI PT, Anderson ER, Casas-Sanchez A, Smith SL, Cansado-Utrilla C, Turtle L, Hughes GL. 2020. Methods of inactivation of SARS-CoV-2 for downstream biological assays. . bioRxiv Prepr Serv Biol.

24. Mendoza E, Manguiat K, Wood H, Drebot M. 2020. Two Detailed Plaque Assay Protocols for the Quantification of Infectious SARS-CoV-2. Current Protocols in Microbiology 57.

25. Nguyen TB, Clifford V, Wahab AA, Sinickas V. 2015. Heat treatment of biochemical samples to inactivate Ebola virus: does it work in practice? Hong Kong Med J 21:378. 
bioRxiv preprint doi: https://doi.org/10.1101/2020.11.02 365015; this version posted November 2,2020 . The copyright holder for this preprint (which was not certified by peer review) is the author/funder, who has granted bioRxiv a license to display the preprint in perpetuity. It is made available under aCC-BY-ND 4.0 International license.

26. Wang Y, Song W, Zhao Z, Chen P, Liu J, Li C. 2020. The impacts of viral inactivating methods on quantitative RT-PCR for COVID-19. Virus Research 285:197988.

27. Pan Y, Long L, Zhang D, Yan T, Cui S, Yang P, Wang Q, Ren S. 2020. Potential false-negative nucleic acid testing results for Severe Acute Respiratory Syndrome Coronavirus 2 from thermal inactivation of samples with low viral loads. Clin Chem doi:10.1093/clinchem/hvaa091.

28. Zou J, Zhi S, Chen M, Su X, Kang L, Li C, Su X, Zhang S, Ge S, Li W. 2020. Heat inactivation decreases the qualitative real-time RT-PCR detection rates of clinical samples with high cycle threshold values in COVID-19. Diagnostic microbiology and infectious disease 98:115109115109.

29. Wang Y, Wu X, Wang Y, Li B, Zhou H, Yuan G, Fu Y, Luo Y. 2004. Low stability of nucleocapsid protein in SARS virus. Biochemistry 43:11103-11108. 


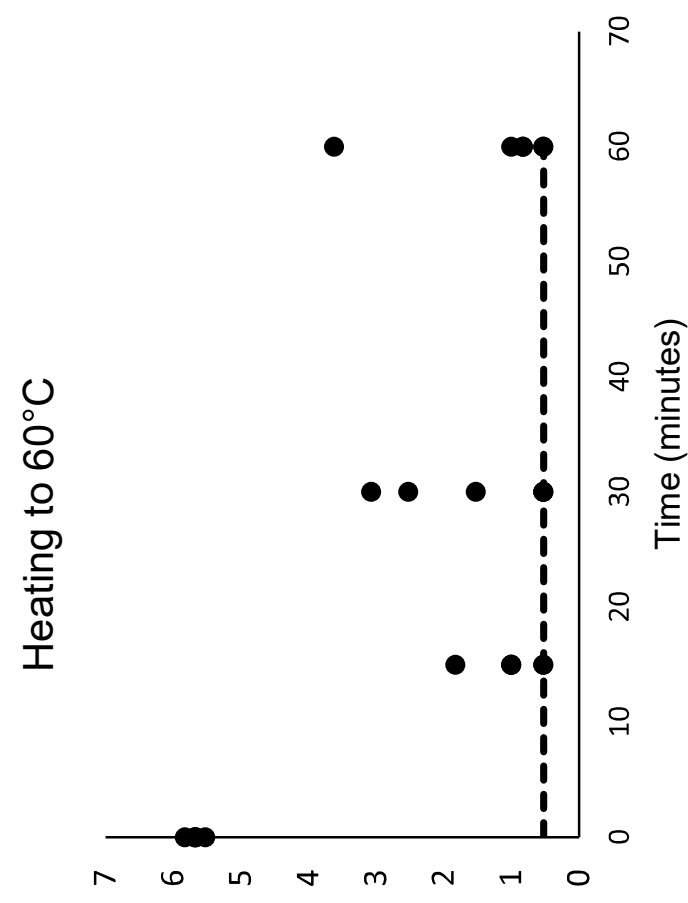

$($ ( $\mathrm{m} / \mathrm{n} \exists \mathrm{d} 0\llcorner\mathrm{60})$

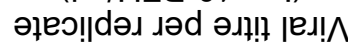

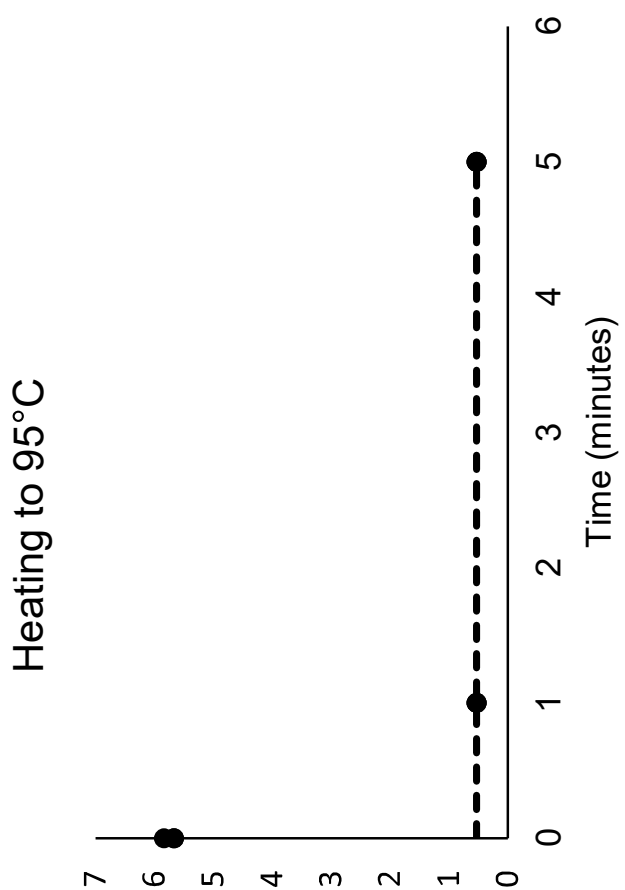

(ן/ח/n- ${ }^{\circ / 607)}$

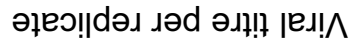

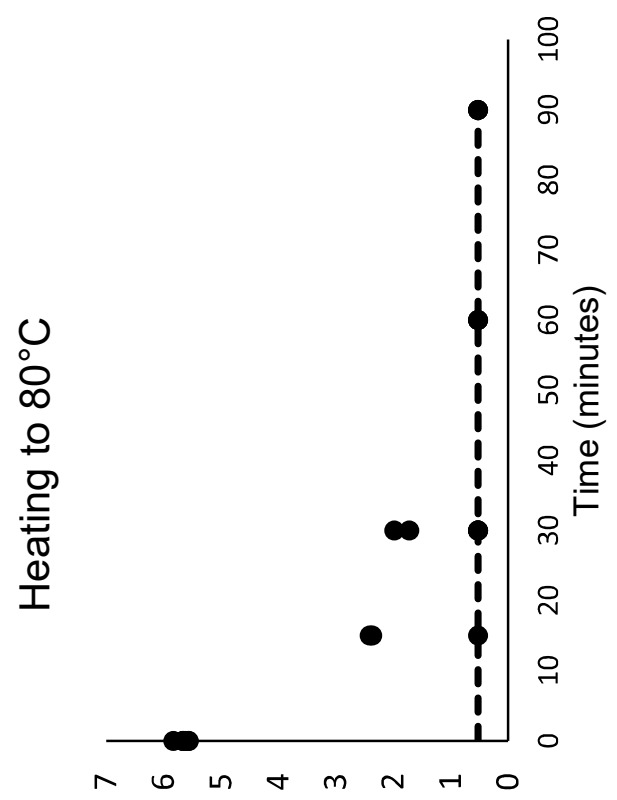

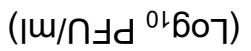

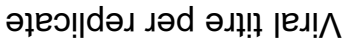




\section{Figure 1. Legend}

In each experiment the heat treatment was performed in triplicate on identical $1 \mathrm{ml}$ volumes of SARS-CoV-2 England 2 virus in tissue culture medium. Each point represents the mean titre of three wells for each replicate at each temperature/time point $\left(\log _{10} \mathrm{pfu} / \mathrm{ml}\right)$. Heat treatments at $60^{\circ} \mathrm{C}$ and $80^{\circ} \mathrm{C}$ were conducted twice (on separate days). The dotted line represents the limit of detection of the plaque assay. 